wide compared, with the size of the corpus and the area of the chewing surface.

(5) The molar-premolar series are remarkably convergent anteriorly as in man, and not parallel or convergent posteriorly as is usual in the great apes.

(6) The form of the condylar process approximates more to that seen in man than to that in the living apes. Unfortunately, this part of the mandible is unknown in any other fossil ape.

(7) Viewed from the front, the mandible has a certain general resemblance to the human form.

(8) The flat wear of the molars is reminiscent of that seen in Eoanthropus and man rather than the type of wear seen in the great apes. On the other hand, the canine is large. The third molar exhibits the typical Dryopithecus pattern of the cusps, and the premolars, though reduced in size, are more anthropoid than human in character.

This new mandible is assigned to the genus Proconsul originally described by Dr. A. T. Hopwood from fragmentary material from Koru, Kenya, but it does not seem to bear out his interpretation that "the genus is ancestral to the chimpanzee", but rather supports and gives added point to the view expressed by Drs. Gregory and Hellman, that Proconsul stands "near to the common ape-man stem".

I would like to express my thanks for the comments sent to me by Sir Arthur Keith, Prof. Le Gros Clark and Dr. W. K. Gregory as a result of notes and phetographs sent to them soon after the discovery was made.

${ }^{1}$ E. African Nat. Hist. Soc., Nairobi, Kenya (in the press).

\section{CONFERENCE ON THE FUTURE OF ARCH/EOLOGY}

\section{BY KATHLEEN M. KENYON \\ Acting Director, Institute of Archæology, University of London}

A $\mathrm{T}$ the present time, the thoughts of many people are turning to the problems of the post-war period. Many of these problems are material and in the economic sphere, but equally important are those in the cultural and educational sphere. Some archæologists have been considering in what way and by what means archæology is going to make its contribution to the post-war period, and during August 6-8 a conference on the Future of Archæology was held at the Institute of Archæology of the University of London, at which some 280 people were present, including most of the leading archæologists at present in the country.

The dominant theme was that archæology, as Mr. W. J. Varley expressed it, was no longer the pursuit of a very recondite erudition by a select few in a quiet temple dedicated to no other purpose. It was a study which could clothe the past with reality, through which man can achieve what is essential if he is to survive, a sense of community with all other men in the world of space. Dr. Grahame Clark, who opened the conference with a paper on the "Contribution of Archæology to the Post-War World", put the claim of archæology to be of value to every: one, in his statement that it not only gave to old and young alike an understanding of the birth and growth of culture in their own lands, but it also provided a basis of common understanding between men of all nations, since the early history of mankind in the Palæolithic period, for example, formed a common heritage of all men.

Prof. V. G. Childe, in a stimulating paper on the "Unity of Archæology", stressed again this same point. The different branches of archæology had grown up by varied means. Classical archæology, due to its antiquarian ancestry, had developed from a search for monuments, coins and inscriptions. Mesopotamian archæology was originally interested almost entirely in tablets and sculptures, while prehistoric archæology, owing to the lack in.this sphere of more spectacular relics, was compelled to devote attention to everyday objects, and the way of life of the common man. Gradually, however, all branches were coalescing and making as their common aim that of recovering and reviving the life of societies of the past from their concrete remains, and to do this all branches were borrowing methods from the others. A unity of approach was highly important, since archæology alone can tell how and in what directions humankind has progressed. Written history is too brief, and only archæology can survey men and their achievements over half a million years in every ccrner of the globe.

The problem next in importance to be discussed was how archæology, granted thus to be important to all, could be placed before the public in an interesting and palatable form. In a session devoted to "Archæology and Education", the different ways that the subject could be introduced into elementary, secondary, university and adult education were discussed, and the matter came in again in the session on "Museums and the Public". Archæolcgy, through reconstruction and visible remains, can make local history live both to children and adults, and the child who could see actual Roman leather shoes, and the British workman who could carry through voluntarily an arduous excavation in order to see what sort of a job his Iron Age ancestor had made of digging a rock-cut ditch, were gaining something which no amount of lessons or lectures could give. Many illustrations were given of the widespread interest there is in the concrete history of the past. To meet this, archæologists must be prepared to popularize their science. All teachers of history, geography and art should have a grounding in archæology, and something should also be done to bring home to men of science that life is not all atoms and formulæ, but that some kind of historical knowledge or understanding is essential to make them educated men and women.

Other sessions were devoted to the actual problems, both archæological and of organization, of the future. Speakers outlined the problems needing attention in the different fields. Both Britain and the Near and Middle East were covered by a number of papers, and detailed suggestions of needs for the different countries were made, while during the discussions, emphasis was laid on the fact that areas such as Central Asia, the Far East and South America should not be neglected. A very special problem was set by the opportunities given by war damage for the examination, before reconstruction, of sites both in Britain and the Mediterranean area, and adequate provision for this must be made. The need for planning was continually referred to, but Mr. J. N. L. Myres made the very important point that planning must be elastic and must neither curb individual initiative nor regiment research. 
In all the addresses there kept recurring the view that, in the conditions to be expected in the post-war period, archæology would be financially in a difficult position. Though some speakers felt that security was undesirable, and that archæologists were the more devoted from having to stump the country raising funds, as did Sir Flinders Petrie, the general consensus of opinion was that unless some reasonable prospect of a livelihood was held out many promising students would be lost. The growing difficulties of archæological societies were pointed out by both Prof. Alan Gardiner in his comparison of the palmy days of the Egypt Exploration Society at the end of the last century with its present state, and by $\mathrm{Mr} . \mathrm{H}$. St. George Gray in his survey of the responsibilities and commitments of the local British societies. Many felt that some form of State assistance was both justifiable and necessary. Others, however, feared that any form of State assistance would involve State control, which might hamper the freedom of research. A solution advocated by Mr. Grimes, and supported by many, was that in connexion with some State organization co-ordinating the different bodies at present concerned with State archæology, there should be some form of grants, made through a responsible archæological body, which would ensure that research as such was adequately endowed, but free of officialdom. Sir Leonard Woolley put forward an eloquent plea for State support for British schools of archæology abroad, with the suggestion that these should be sponsored by the British Council. Other speakers supported his plea for strong British schools, though they deprecated any suspicion that archæology should be used as a means of official dissemination of British culture. Good relations would result from them, particularly if they were open to the nationals of the country in which they were established, but they would be a by-product of the main end, the furtherance of knowledge.

The other main subject discussed was the "Training of Archæologists". The point was strongly made that excavators must receive a sound training in field work. Archæologists in the past had mainly learnt from experience and experiment, usually at the expense in the early stage of a partial destruction of the evidence of an archæological site, and it must be realized, as Mr. I. A. Richmond said, that Roman villas do not exist to provide a Roman holiday for amateurs. The need for training in the environmental sciences was stressed by Dr. F. E. Zeuner. Archæologically-minded geologists and biologists should acquaint archæological students with the processes or phenomena investigated by those sciences, in order that they may know how best to make usi of the specialists.

The results of the Conference may thus be summarized: the setting out of the vital contribution which archæology can make to the education of mankind, and the means by which this can be achieved; the emphasis laid on the need for additional financial resources, and the suggestions as to how these should be fortheoming from the State; and the suggestions as to how archæologists should be trained. The Conference closed with a resolution that the problems should be referred to the appropriate bodies for action, those affecting Britain to the newly formed Council for British Archæology, and those affecting work overseas to the societies interested, with the suggestion that they should set up an appropriate organization to deal with them.

\section{OBITUARIES}

\section{Prof. Frank Schlesinger}

THE name of Frank Schlesinger will always be associated with the determination of stellar parallaxes, for to him is mainly due the considerable knowledge of stellar distances that we now have. It was a fortunate circumstance that his postgraduate research was carried out at the Columbia University, where at the close of the nineteenth century astronomical research work was mainly concerned with the problems of the accurate determination of star positions by means of photography. The great possibilities that photography offered in this field were just beginning to be realized. Schlesinger's thesis for the Ph.D. degree was concerned with the accurate measurement and reduction of photographs of the Præsepe cluster, obtained by Rutherfurd, and showed originality of mind, a thorough grasp of fundamental principles, and ingenuity of method. He was quick to see the possibilities that photography offered for the accurate determination of stellar parallaxes. A short paper, published in 1899, entitled "Suggestions for the Determination of Stellar Parallax by means of Photography", referred to the neglect of this important subject and estimated that not more than twenty-five or thirty stars had known parallaxes which could be relied on to within $0 \cdot 05^{\prime \prime}$. It outlined methods which Schlesinger was himself afterwards to develop, and showed that he already clearly saw the main precautions that were needed to obtain accuracy.

A few years were to elapse, however, before Schlesinger could try out the suggested methods. He was appointed in 1899 to take charge of the newly established International Latitude Observatory at Ukiah, Ca., but the opportunity came with his appointment in 1903 to the staff of the Yerkes Observatory. He at once started parallax observations with the great 40 -in. refractor. In a remarkably short time he developed methods that have since been closely followed by every observer who undertakes the determination of stellar parallaxes. In 1905 Schlesinger was appointed director of the Allegheny Observatory, which had just been reorganized, and for a time his attention was devoted to other problems, mainly of a spectroscopic nature. The results of the work at Yerkes were published in 1910-11 in seven important papers, which have deservedly become classics in this field of investigation. The methods of observation, the possible sources of error and how they could be eliminated or reduced to a minimum, the methods of measurement and of reduction were all comprehensively discussed. For the measurement of the plates Schlesinger designed an excellent long-screw measuring engine, which was made by Brashear. Many other engines of the same design have since been made by Gaertner.

It was characteristic of Schlesinger, when planning large programmes of observations, to consider carefully the accuracy attainable in relation to the expenditure of time in observation and measurement. There is generally a point beyond which further accuracy can be obtained only at the expense of a disproportionate increase in time and labour. As an example, Kapteyn had proposed that parallax plates after exposure should be stored undeveloped for six months or so and then exposed again, so that the parallactic displacement could be determined by differential measurements and the effects of film 